\title{
The overexpression of multidrug resistance-associated proteins and gankyrin contribute to arsenic trioxide resistance in liver and gastric cancer cells
}

\author{
XI CHEN, MU ZHANG and LIAN-XIN LIU \\ General Surgery, The First Affiliated Hospital of Harbin Medical University, Harbin, P.R. China \\ Received January 9, 2009; Accepted March 3, 2009 \\ DOI: $10.3892 /$ or_00000408
}

\begin{abstract}
Arsenic trioxide has been used as a therapeutic agent for acute promyelocytic leukemia and recently for some solid tumors. Although arsenic trioxide has been shown to significantly inhibit the growth of solid tumor cells in vitro, clinical trials indicate that arsenic trioxide alone is pool active against non-hematologic malignant diseases. To understand the mechanisms of arsenic resistance in solid tumor cells, we established two arsenic-resistant solid tumor cell lines, HepG2/AS and SGC7901/AS, isolated from human liver cancer cell line HepG2 and human gastric cancer cell line SGC7901, respectively, by a series of stepwise selections via treatment with increasing concentrations of arsenic trioxide. Three $\mathrm{ABC}$ transporter proteins, $\mathrm{ABCB} 1, \mathrm{ABCC} 1$ and $\mathrm{ABCC} 2$, were expressed increasingly and differently in two arsenic-resistant cell lines. Further, tumor suppressor p53 was overexpressed in two arsenic-resistant cell lines, but the levels of p53 mediators MDM2 and gankyrin, which regulate the ubiquitination of p53, increased simultaneously. In addition, an increase in the phosphorylation of $\mathrm{Rb}$ at Ser795 in the two cell lines might also result from the presence of MDM2 and gankyrin, which suggest that the inactivation of p53 and $\mathrm{Rb}$ contribute to drug resistance. These two arsenic-resistant solid tumor cell lines, HepG2/AS and SGC7901/AS, may be useful for studying the mechanism of arsenic resistance in solid tumors and may provide a way to overcome it.
\end{abstract}

\section{Introduction}

Arsenic trioxide $\left(\mathrm{As}_{2} \mathrm{O}_{3}\right)$, a traditional Chinese medicine, has been used therapeutically for many years. It is widely used as an effective anti-cancer drug for acute promyelocytic leukemia

Correspondence to: Dr Xin Lian Liu, The Sixth Ward of General Surgery, First Clinical College of Harbin Medical University, 23\#, You zheng Street, Nan gang District, Harbin, Heilongjianig Province, P.R. China

E-mail: liulianxin@medmail.com.cn

Key words: arsenic trioxide, resistance, multidrug-resistant protein, gankyrin, MDM2
(APL). Arsenic trioxide degrades the PML-RAR $\alpha$ fusion protein in APL cases characterized by chromosomal translocation $\mathrm{t}(15 ; 17)$ and rearrangement of the promyelocytic leukemia (PML) gene and retinoic acid receptor $(\mathrm{RAR} \alpha)$ gene and induces differentiation in lower concentrations $(1,2)$. Unlike all-trans retinoic acid (ATRA), arsenic trioxide affects multiple intracellular signaling pathways and induces apoptosis of APL cells, with a higher concentration independent of the presence of the PML-RAR $\alpha$ fusion protein. Similarly, increasing evidence has shown that this inorganic arsenic compound can effectively inhibit the growth of solid tumors in the digestive tract by inducing apoptosis in vitro and in vivo, especially liver cancer, because most inorganic arsenicals are biotransferred in the liver $(3,4)$.

Although hepatocellular carcinoma (HCC) is common, only rarely is it treatable by surgery. Systemic chemotherapy is difficult for patients with HCC to tolerate because hepatic function is often impaired by the invasion of malignant cells, by cirrhosis and by pool homeostasis. The lack of any clinically useful drug therapy for patients with advanced HCC poses difficulties also for physicians. Years before the noticeable anti-cancer activity of arsenic trioxide attracted the attention of oncologists, the effective therapeutic results in vitro and in vivo were surprising. However, recently a phase II trial evaluating the efficacy and toxicity of arsenic trioxide in patients with HCC showed that single-agent arsenic trioxide is pool active against advanced HCC (5). Although several likely factors could explain the inefficacy of arsenic trioxide against advanced HCC, the appearance of drug resistance might be an important possibility.

Drugs fail to kill cancer cells for several reasons. Increasing efflux of anti-cancer drugs is most commonly encountered in laboratories and clinical medication mediated by membrane transporters. The ABC (ATP-binding cassette) transporter family is well known in this area, especially such members as ABCB1 [P-gp, P-glycoprotein, MDR1 (multidrug-resistance gene 1), ABCC1 (multidrug-resistant protein 1, MRP1)], ABCC2 (MRP2) and ABCG2 [breast cancer resistance protein (BCRP)] $(6,7)$. The MRPs have been functionally characterized as the property of ATP-dependent export pumps for conjugates with glutathione (GSH), glucuronate, or sulfate (8). With respect to arsenic compounds, GST (glutathione $S$-transferase) has been reported to conjugate glutathione to arsenicals and several GST isoforms and genetic polymorphisms might influence arsenic metabolism and susceptibility (9). It should 
be pointed out that the arsenic-GSH conjugates are the substrates of some ABC transporter proteins, which efflux them outside mammalian cells (10). In arsenic trioxide-resistant human leukemia cell line K562/AS-3, the main mechanism of tolerance seems to be drug efflux by MRP1 (11). Chronic exposure to low-concentration arsenic trioxide or methylated arsenicals can increase the expression of P-gp, MRP1 and MRP2 at both the protein and mRNA level $(12,13)$. However, there is no established arsenic-resistant human solid tumor cell line. Therefore, which of the ABC members contribute to arsenic resistance by actively pumping arsenic compounds outside solid tumors derived from the human digestive tract is still uncertain.

It is known that arsenic trioxide induces DNA damage and p53 accumulation and that arsenic trioxide-induced apoptosis is required for p53 $(14,15)$. Reducing the expression or inhibiting the function of p53 may abrogate the apoptosis of tumor cells induced by arsenic trioxide. Several signaling pathways are involved in the regulation of p53; of these, ubiquitylation is the most common way for the degradation of p53 through the binding of MDM2 to p53 (16). Previously, studies further verify that gankyrin promotes both mono- and poly-ubiquitylation of p53 by MDM2 in a p300-independent manner (17). Direct interaction between gankyrin and MDM2 is necessary to enhance p53 ubiquitylation and gankyrin facilitates the binding of MDM2 to p53 in vivo and in vitro. This suggests that gankyrin could be a key point in the regulation of p53 and may contribute to the establishment of resistance to arsenic trioxide in tumor cells. Thus, we established two arsenic-resistant solid tumor cell lines, HepG2/AS and SGC7901/AS to investigate the reasons of resistance. Our results indicate that HepG2/AS seems to efflux arsenic compounds mainly by $\mathrm{ABCB} 1, \mathrm{ABCC} 1$, and ABCC2, whereas SGC7901/AS seems to efflux arsenic compounds mainly by $\mathrm{ABCB} 1$. Inactivation of $\mathrm{ABCB} 1$ by higher concentration of verapamil can restore the sensitivity of arsenic trioxide in HepG2/AS and SGC7901/AS. Increasing the levels of gankyrin and MDM2 may enhance the degradation of p53 and the phosphorylation of $\mathrm{Rb}$, resulting in abrogation of apoptosis. A better understanding of arsenic resistance in solid tumor cells may provide novel targets for treating arsenic-resistant tumors and promote screening of suitable patients.

\section{Materials and methods}

Reagents. $\mathrm{As}_{2} \mathrm{O}_{3}$ (Sigma, St. Louis, MO, USA) was dissolved in phosphate-buffered saline (PBS) at $200 \mu \mathrm{M}$ as a stock solution, which was stored at $4^{\circ} \mathrm{C}$. For in vitro use, the stock solution was diluted to the appropriate concentration in growth medium. Fluorouracil (5-FU; Sigma) was dissolved in medium at $100 \mu \mathrm{g} / \mathrm{l}$ as a working solution, which was stored at $4^{\circ} \mathrm{C}$. Verapamil (Sigma) was dissolved in PBS at $1 \mathrm{mM}$ as a stock solution, which was stored at $4^{\circ} \mathrm{C}$. Cell counting kit-8, 2-(2-methoxy-4-nitrophenyl)-3-(4-nitrophenyl)-5-(2,4disulfophenyl)-2H-tetrazolium monosodium salt (WST-8) was purchased from Beyotime Institute of Biotechnology (Shanghai, China). Gibco cell culture medium RPMI-1640 and fetal bovine serum were purchased from Invitrogen (Shanghai).
Cell culture. HepG2/AS and SGC7901/AS were isolated from the human liver cancer cell line, HepG2, and the human gastric cancer cell line, SGC7901, by a series of stepwise selections via treatment with increasing concentrations of arsenic trioxide. HepG2, HepG2/AS, SGC7901 and SGC7901/AS were cultured and passaged in RPMI-1640 supplemented with $10 \%$ fetal bovine serum in a $5 \% \mathrm{CO}_{2}$ incubator at $37^{\circ} \mathrm{C}$. HepG2/AS and SGC7901/AS were maintained in medium containing $2 \mu \mathrm{M} \mathrm{As}_{2} \mathrm{O}_{3}$.

Cytotoxicity. Cytotoxicity assays using WST-8, modified from the MTT assay, were performed. Briefly, $1 \times 10^{4}$ cells were plated per well with $100 \mu 1$ of medium in 96-well microtiter plates. Cells were grown for $24 \mathrm{~h}$, after which arsenic trioxide was added; the final concentration of the medium was $4 \mu \mathrm{M}$ $\mathrm{As}_{2} \mathrm{O}_{3}$. After an additional 12, 24, 36 and $48 \mathrm{~h}$ of incubation, the medium was aspirated and the WST- 8 solution was added. After incubation at $37^{\circ} \mathrm{C}$ for $1.5 \mathrm{~h}$, the optical density of each well was determined in a microplate reader by an absorbance spectrophotometer at a wavelength of $450 \mathrm{~nm}$. Cell viability was measured and was expressed as a percentage of absorbance in the vehicle-treated control wells.

Western blot analysis. Protein extracts from total cells were harvested in radioimmunoprecipitation assay buffer [0.15 M $\mathrm{NaCl} / 0.05 \mathrm{mM}$ Tris-HCl; pH 7.2/1\% NP-40/1\% sodium deoxycholate $/ 0.1 \%$ sodium dodecyl sulfate (SDS)] with $1 \mathrm{mM}$ phenylmethyl sulfonylfluoride and then subjected to $10,000 \mathrm{x} \mathrm{g}$ centrifugation at $4^{\circ} \mathrm{C}$ for $10 \mathrm{~min}$. Protein levels were quantified using a bicinchoninic acid protein assay (Beyotime Biotechnology). A total of 40 to $50 \mu \mathrm{g}$ of total protein was separated by denaturing electrophoresis. The following antibodies were used for immunoblotting: mouse monoclonal anti-ß-actin antibody (C4), mouse monoclonal anti-MDR1 antibody (D-11), mouse monoclonal anti-MRP1 antibody (QCRL-1), mouse monoclonal anti-MRP2 antibody (6D564), rabbit polyclonal anti-gankyrin antibody (H-231), mouse monoclonal anti-p53 antibody (DO-1), mouse monoclonal anti-MDM2 antibody (SMP14), rabbit polyclonal anti-Rb antibody (C-15), and goat polyclonal anti-p-Rb (Ser795) antibody (sc-7986), all purchased from Santa Cruz Biotechnology (Santa Cruz, CA, USA). After SDS-PAGE (polyacrylamide gel electrophoresis) proteins were transferred to PVDF (polyvinylidene fluoride) sheets. After blocking with TTBS (50 mM Tris-HCl; pH 7.4; $0.5 \mathrm{M} \mathrm{NaCl} ; 0.05 \%$ Tween-20) containing $5 \%$ (weight per volume) skim milk, the sheets were incubated with primary antibodies at $4^{\circ} \mathrm{C}$ overnight. Blots were then detected with a BeyoECL plus kit (Beyotime Biotechnology).

Real-time polymerase chain reaction. All primer pairs were designed to cross at least one intron. Reverse transcription was performed using Takara Ex Taq (Takara, China) with 50 ng RNA per $20 \mu 1$ of reaction mixture. For real-time polymerase chain reaction (PCR), we used the ABI PRISM 7900 HT [Applied Biosystems (formerly Applera Corporation), Foster City, CA, USA] in standard mode. In a total 25- $\mu 1$ reaction system, there are $20-\mu \mathrm{M}$ probes, $20-\mu \mathrm{M}$ forward/ reverse primers, 12.5- $\mu$ 1 ABI TaqMan $2 \mathrm{X}$ PCR master mix and $2-\mu 1$ templates. The experiments were performed three times. PCR products were normalized against the housekeeping 

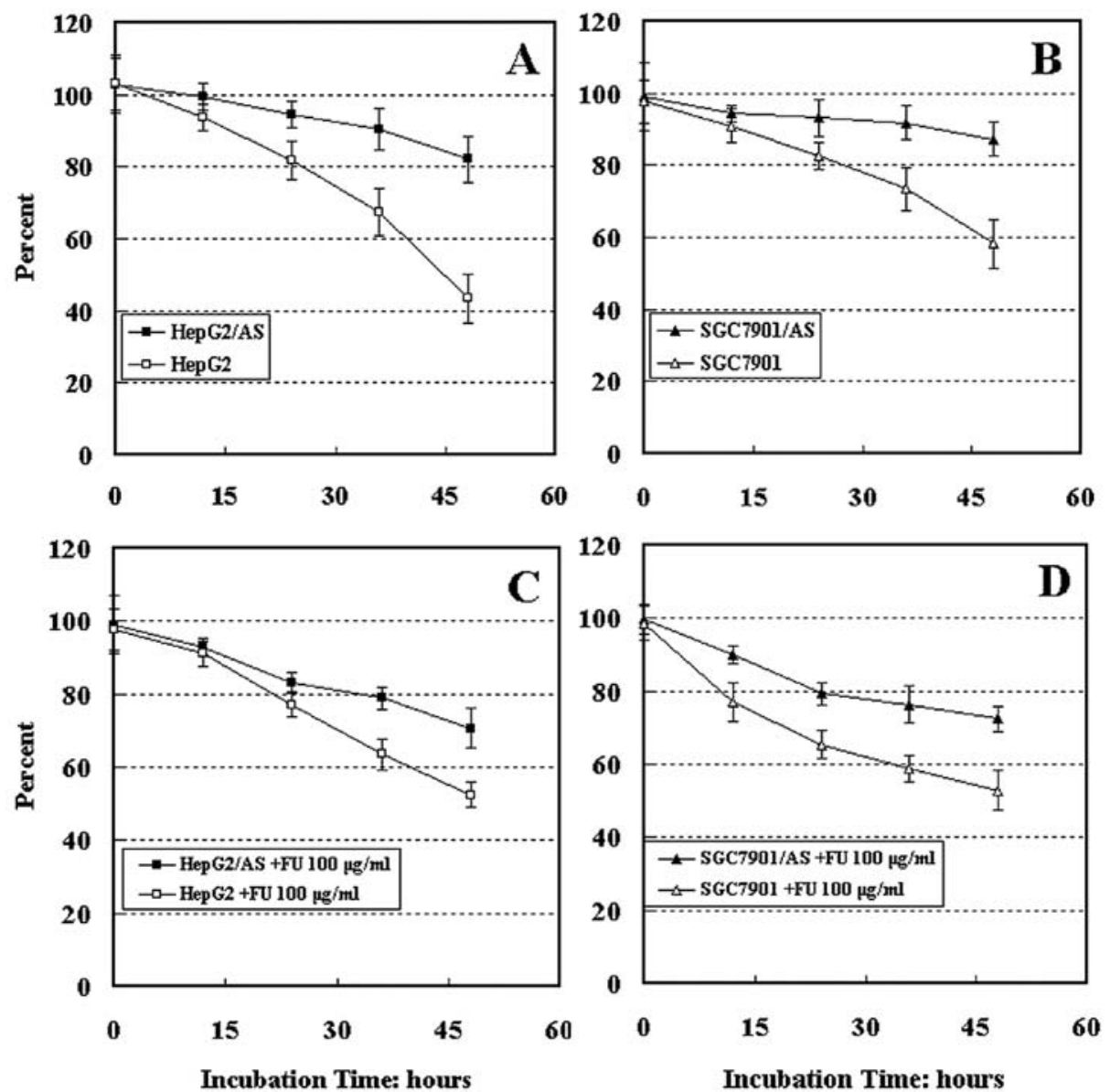

Figure 1. Effects of $4 \mu \mathrm{M} \mathrm{As}_{2} \mathrm{O}_{3}$ in HepG2, HepG2/AS (A) and in SGC7901, SGC7901/AS (B). Effects of $100 \mu \mathrm{g} / \mathrm{l}$ fluorouracil in HepG2, HepG2/AS (C) and in SGC7901, SGC7901/AS (D). Cells (1x10 $)$ were seeded in the 96-well plates. The cells were incubated at $37^{\circ} \mathrm{C}$ in the presence of As $\mathrm{O}_{3}$ for 48 h. Cell viability was assessed by the CCK-8 assay. Values are means \pm SD of at least three independent experiments performed in triplicate. $\square$, HepG2; $\square$, HepG2/AS; $\square$, SGC7901; $\boldsymbol{\Delta}$, SGC7901/AS.

gene $\beta$-actin and measurements between samples were compared by cycle threshold $(\mathrm{Ct})$. The primers used in real-time PCR were as follows: forward primers: ABCB1 5'-GCTCAGACAGGATGTGAGTTGGT-3'; ABCC1 5'-AGG TCAAGCTTTCCGTGTACTG-3'; ABCC2 5'-GTGAGGAT TGACACCAACCAGAA-3'; gankyrin 5'-CAATCAAAAT GGCTGTACTCCCTTA-3' reverse primers: ABCB1 5'-CCT GGAACCTATAGCCCCTTTAAC-3'; ABCC1 5'-GGACTT TCGTGTGCTCCTGA-3'; ABCC2 5'-CCCACTTAGGGTA TCTCTATAAATAACCA-3'; gankyrin 5'-TGGTCCTTAG CATCTGGATTAGC-3'.

\section{Results}

Evaluation of arsenic-resistant cell line. HepG2/AS was isolated from wild-type HepG2 by a series of stepwise selections via treatment with increasing concentrations of arsenic trioxide from 0.5 to $4 \mu \mathrm{M}$, referring to the establishment of arsenic resistant human leukemia cell line K562/AS-3 (11). We selected the most resistant cell line and named it HepG2/ AS. HepG2/AS was maintained in medium containing $2 \mu \mathrm{M}$ $\mathrm{As}_{2} \mathrm{O}_{3}$ and cultured for 4 weeks before evaluation. The selection and cultivation of SGC7901/AS was the same as for HepG2/AS. HepG2/AS and SGC7901/AS were significantly more resistant to $\mathrm{As}_{2} \mathrm{O}_{3}$ than were wild-type cells at concen- trations $>4 \mu \mathrm{M}$, according to the assay of cell growth inhibition performed with the CCK-8 assay (Fig. 1). HepG2/AS and SGC7901/AS showed cross-resistance to 5-FU (Fig. 1).

Expression of $A B C B 1, A B C C 1$ and $A B C C 2$ in HepG2/AS and $S G C 7901 / A S$. We examined the protein expression of three $\mathrm{ABC}$ transporters that had been reported to be highly expressed in other drug-resistant cell lines. Western blot analysis confirmed the different expression of ABCB1, ABCC1, and ABCC2 in HepG2, HepG2/AS, SGC7901 and SGC7901/AS. As shown in Fig. 2, although four types of cell lines expressed $\mathrm{ABCB} 1$ on the membrane, the protein was expressed significantly in two arsenic-resistant cell lines. Similarly, the expression of ABCC2 in HepG2/AS was also increased compared with the wild-type. However, the increase of ABCC2 in SGC7901/AS was slight and the amount of $\mathrm{ABCC} 2$ in gastric cancer cells was not as great as that in liver cancer cells. The expression of ABCC1 was increased in HepG2/AS compared with the wild-type. However, there was no obvious expression of $\mathrm{ABCC} 1$ detected in either of the gastric cancer cell lines.

To further confirm the expression of three $A B C B 1, A B C C 1$ and $A B C C 2$ genes, we used real-time PCR, which showed that the increased expression of $A B C B 1$ gene in HepG2/AS was $\sim 2.4$-fold that of the wild-type and that the increased expression 


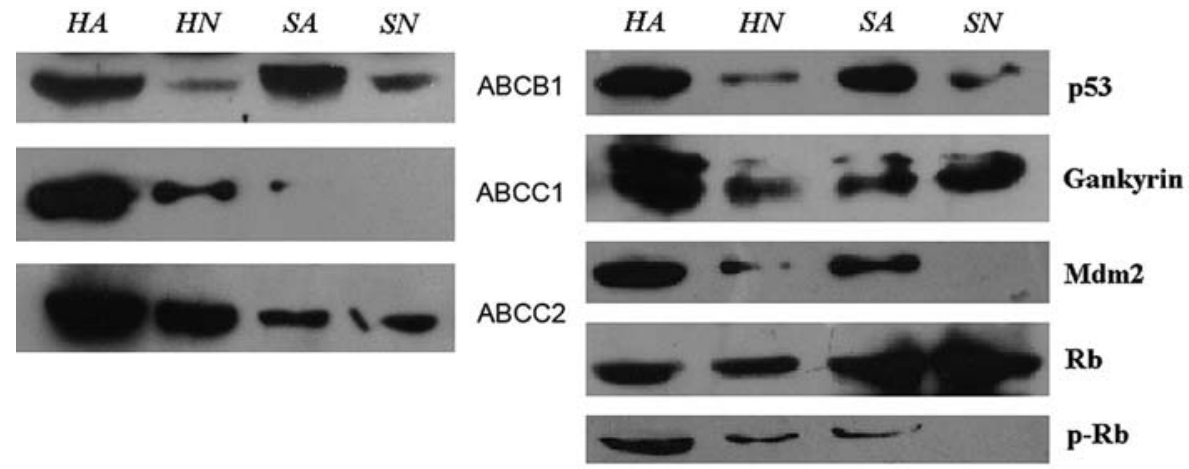

Figure 2. Protein expression in four cell lines by Western blot analysis. Every cell line was incubated for at least 8 weeks as described in the text under 'Cell Culture'. The different expression of $\mathrm{ABC}$ transporters (left), gankyrin and associated proteins (right) between arsenic-resistant cells and the wild-type is shown. In four lanes, HA represents HepG2/AS, HN represents HepG2, SA represents SGC7901/AS and SN represents SGC7901.
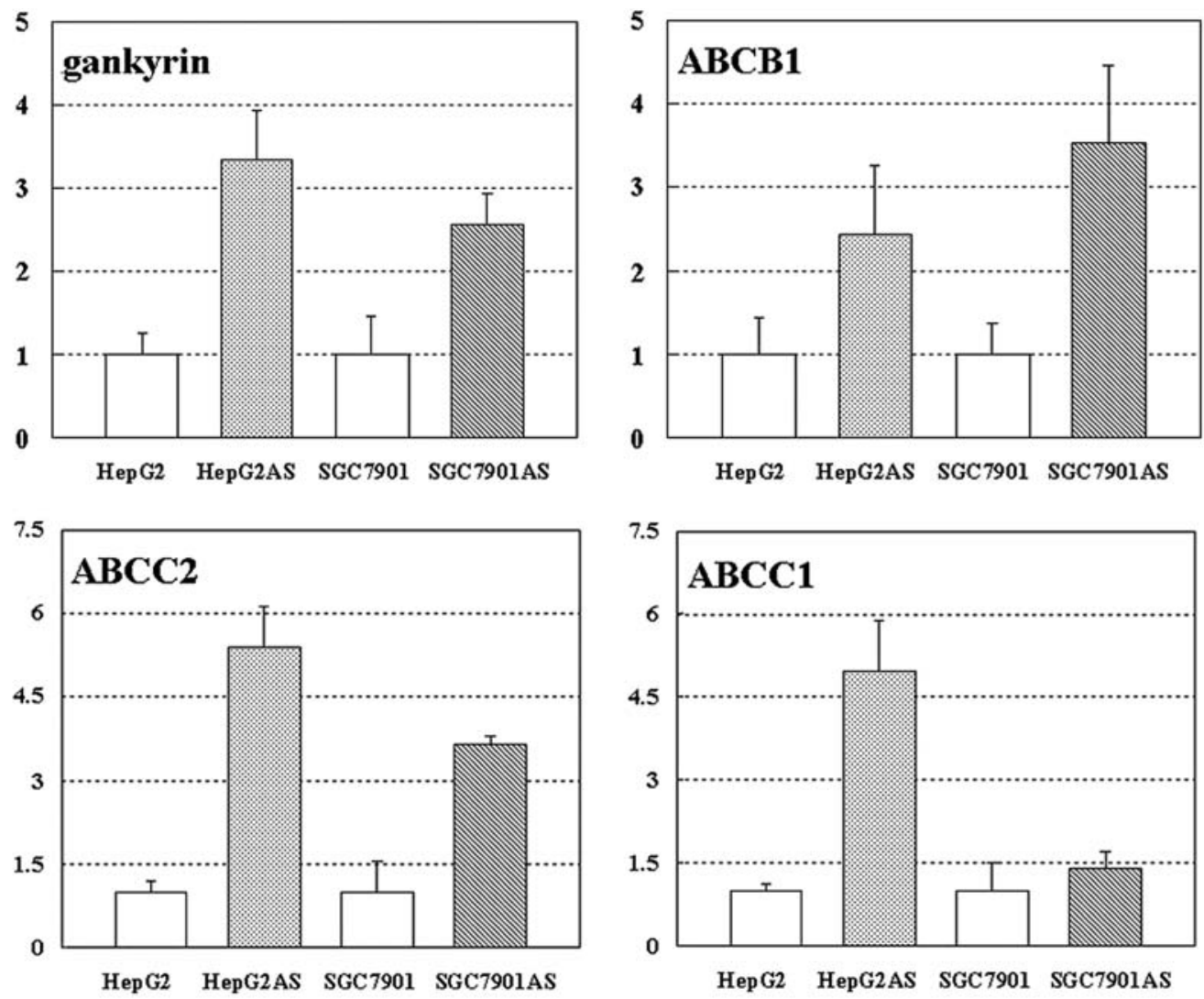

Figure 3. Analysis of gene expression of gankyrin, ABCB1, ABCC2 and ABCC1 in four cell lines by real-time polymerase chain reaction. The copies calculated from cycle threshold were compared between each arsenic-resistant cell line and its relative wild-type. However, copies of each gene were not compared for liver cancer cells and gastric cancer cells. The results are shown as times over (1.5-fold, 3-fold, etc.) in each figure.

in SGC7901/AS was $~ 3.5$-fold that of the wild-type (Fig. 3). The increased expression of the $A B C C 2$ gene in HepG2/AS was $\sim 5.3$-fold greater than in the wild-type and the increased expression in SGC7901/AS was $~ 3.6$-fold greater than in the wild-type. The increased expression of the $A B C C 1$ gene in HepG2/AS was $\sim 5$-fold greater than in the wild-type, but there was no significantly different expression between SGC7901/ AS and SGC7901.

Role of $A B C$ transporters in resistance of HepG2/AS and $S G C 7901 / A S$ to arsenic trioxide. To confirm that the increase of $\mathrm{ABC}$ transporters contributes to the resistance to $\mathrm{As}_{2} \mathrm{O}_{3}$ in
HepG2/AS and SGC7901/AS, we seeded two arsenic-resistant cell lines in 96 -well plates. The cells were incubated at $37^{\circ} \mathrm{C}$ in the presence of $4 \mu \mathrm{M} \mathrm{As}_{2} \mathrm{O}_{3}$, combined with $20 \mu \mathrm{M}$ verapamil, for 48 h. As shown in Fig. 4, there was no significant difference in cytotoxicity in the two resistant cell lines caused by the combination of $\mathrm{As}_{2} \mathrm{O}_{3}$ and verapamil vs. $\mathrm{As}_{2} \mathrm{O}_{3}$ alone. We next incubated four cell lines in the presence of $4 \mu \mathrm{M} \mathrm{As}_{2} \mathrm{O}_{3}$ and/or $50 \mu \mathrm{M}$ verapamil.

Administration of $50 \mu \mathrm{M}$ verapamil alone produced no significant cytotoxicity in resistant and wild-type cells, but the combination of $4 \mu \mathrm{M} \mathrm{As}_{2} \mathrm{O}_{3}$ and $50 \mu \mathrm{M}$ verapamil significantly altered resistance and caused more cell death in two arsenic- 

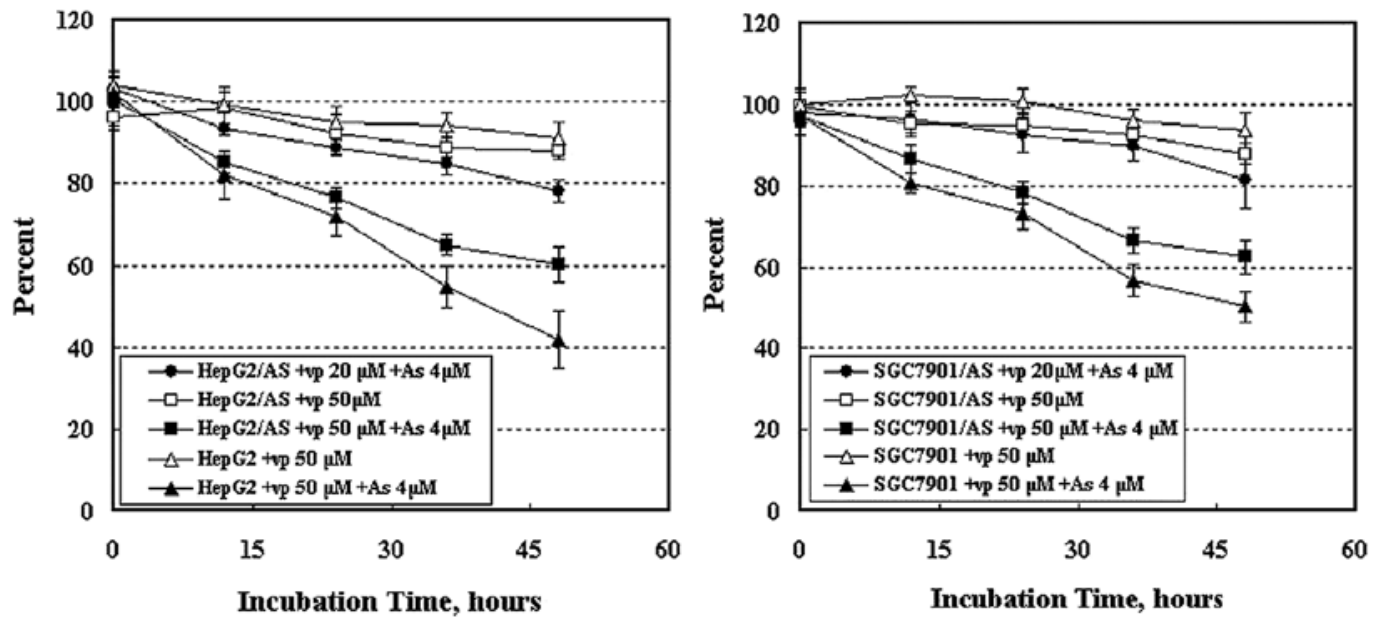

Figure 4. Effects of $4 \mu \mathrm{M} \mathrm{As}_{2} \mathrm{O}_{3}$ combined with 20 or $50 \mu \mathrm{M}$ verapamil in HepG2 (left), HepG2/AS (left), SGC7901 (right) and SGC7901/AS (right). Cells $\left(1 \times 10^{4}\right)$ were seeded in 96 -well plates. The cells were incubated at $37^{\circ} \mathrm{C}$ in the presence of relative drugs for $48 \mathrm{~h}$. Cell viability was assessed by CCK-8 assay. The therapeutic effect of drug combination in two liver cancer cell lines is shown on the left. $\bullet$, HepG2/AS $+20 \mu \mathrm{M}$ verapamil (vp) $+4 \mu \mathrm{M} \mathrm{As} \mathrm{O}_{3}$; $\square$, $\mathrm{HepG} 2 / \mathrm{AS}+50 \mu \mathrm{M}$ vp;, $\mathrm{HepG} 2 / \mathrm{AS}+50 \mu \mathrm{M}$ vp $+4 \mu \mathrm{M} \mathrm{As}_{2} \mathrm{O}_{3} ; \square, \mathrm{HepG} 2+50 \mu \mathrm{M}$ vp; $\mathbf{\Lambda}, \mathrm{HepG} 2+50 \mu \mathrm{M}$ vp $+4 \mu \mathrm{M} \mathrm{As}_{2} \mathrm{O}_{3}$. Values are means $\pm \mathrm{SD}$ of at least three independent experiments performed in triplicate. The therapeutic effect of drug combination in two gastric cancer cell lines is shown on the right.

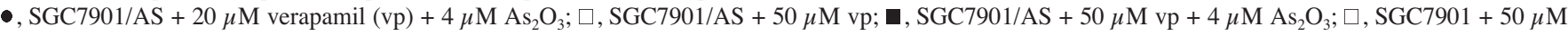
vp; $\mathbf{\Lambda}, \mathrm{SGC7901/AS}+50 \mu \mathrm{M}$ vp $+4 \mu \mathrm{M} \mathrm{As}_{2} \mathrm{O}_{3}$.

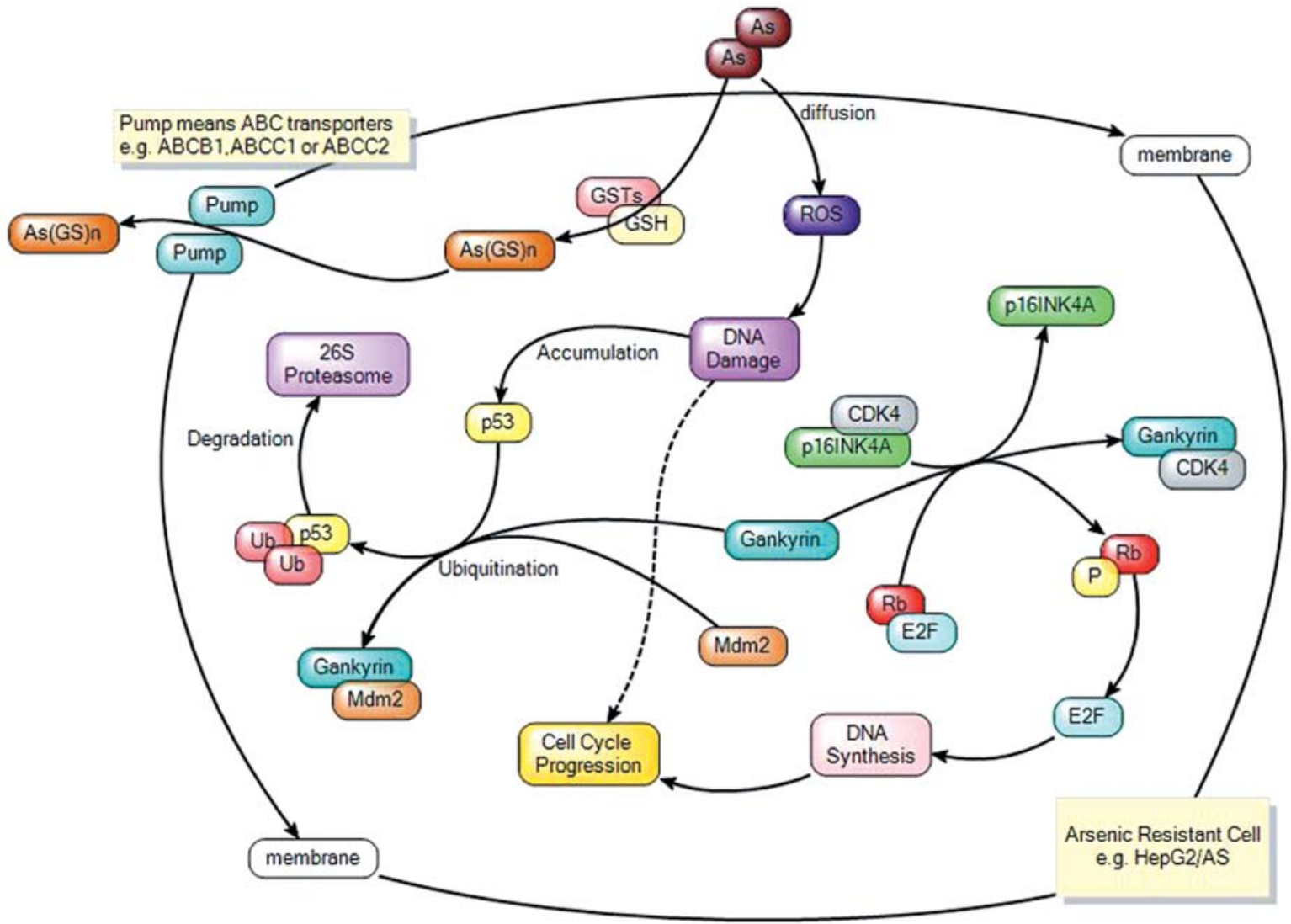

Figure 5. The probable mechanisms of arsenic resistance in solid tumor cells (e.g., HepG2/AS).

resistant cell lines. However, despite the effective inhibition of $\mathrm{ABC}$ transporters by $50 \mu \mathrm{M}$ verapamil, the survival rate in the resistant group was $\sim 10$ to $20 \%$ higher than in the wild-type group.
Intracellular regulation of tumor suppressors in HepG2/AS and SGC7901/AS. We examined the expression of p53 in four cell lines, a key factor in apoptosis induced by arsenic trioxide. As shown in Fig. 2, the expression of p53 was increased in 
HepG2/AS and SGC7901/AS, which showed resistance to arsenic cytotoxicity, indicating that the activity of p53 might be inhibited. Next, we examined the expression of two proteins participating in the regulation of $\mathrm{p} 53$. We found that the expression of MDM2 was also increased in two resistant cell lines compared with the wild-type. Studies have shown that overexpression of gankyrin suppresses p53-dependent apoptosis in tumor cells. In our study, gankyrin was significantly increased in HepG2/AS but slightly decreased in SGC7901/AS. We again used real-time PCR to analyze the expression of the gankyrin gene in four cell lines. The increased expression of gankyrin in HepG2/AS was 3.3-fold that of the wild-type. However, the expression of the gankyrin gene in SGC7901/AS was increased by $\sim 2.5$-fold over the wild-type, which was a paradoxic finding, considering its protein level. Besides p53, gankyrin can also affect the activity of $\mathrm{Rb}$, another tumor suppressor. Thus, we subsequently examined the expression of $\mathrm{Rb}$ and $\mathrm{p}-\mathrm{Rb}$ (Ser795), which was phosphorylated depending on gankyrin overexpression. The expression of $\mathrm{Rb}$ was no different in the resistant cell line vs. the relative wild-type, whereas the expression of $\mathrm{p}-\mathrm{Rb}$ (Ser795) was increased in two resistant cell lines compared with the wild-type. These results suggested that $\mathrm{Rb}$ was inactive and phosphorylated at Ser795 by gankyrin in HepG2/AS; however, the phosphorylation of Rb in SGC7901/AS appeared to have no association with gankyrin.

\section{Discussion}

Solid tumors in the digestive tract are common, especially $\mathrm{HCC}$ and gastric cancer. Although surgery is the optimal treatment for solid tumors, systemic and partial chemotherapy could be necessary for patients with in situ or metastatic cancer. Decades ago, arsenicals were considered to be carcinogenic toxins. However, after the ability of arsenic trioxide to induce differentiation and apoptosis against APL was discovered, it was extensively used as an effective drug for leukemia. Previously, it has also been used in therapy for solid tumors such as HCC, gastric cancer, colorectal cancer, and renal cancer (18-20). Although a significant anti-cancer effect had been reported in preclinical and clinical trials, failure of chemotherapy was reported frequently in patients and some cell lines (5). Among the reasons anti-cancer drugs fail, the most common is acquired drug resistance.

Although the possible mechanism of arsenic resistance has been investigated in rat liver cells and human leukemia cells, the mechanism of arsenic resistance in human liver and gastric tumors has not been clarified yet. We established two cell lines resistant to arsenic trioxide, HepG2/AS and SGC7901/ AS, derived from human liver cancer cell line HepG2 and human gastric cancer cell line SGC7901, respectively, referring to the establishment of human leukemia cell line K562/AS-3, which is resistant to arsenic trioxide (11).

Two arsenic-resistant cell lines were cultured in $2 \mu \mathrm{M}$ $\mathrm{As}_{2} \mathrm{O}_{3}$ medium, a concentration that was reportedly clinically achievable without severe side effects (1) and appeared more resistant to arsenic compounds even in $4 \mu \mathrm{M} \mathrm{As}_{2} \mathrm{O}_{3}$ compared with the wild-type. Long-term exposure to low levels of organic arsenicals produced self-tolerance to acute arsenic exposure, accompanied by reduced cellular arsenic accumulation. Studies have also demonstrated increased expression of genes encoding GST isoforms and ABC transporters MRP1, MRP2 and P-gp in cells chronically exposed to arsenic at both the transcriptional and translational levels $(13,21,22)$. GST facilitate the formation of putative arsenic-GSH conjugates, such as arsenic triglutathione and dimethylarsenic diglutathione, resulting in more effective cellular or biliary excretion (23-25). Notably, arsenic-GSH conjugates are the substrates of some MRP proteins, which efflux them outside mammalian cells. Therefore, ABC transporters might be the end point in the process of arsenic biotransformation and endue cells with acquired arsenic resistance. Consistently $\mathrm{ABCB} 1, \mathrm{ABCC} 1$ and $\mathrm{ABCC} 2$ were significantly increased in $\mathrm{HepG} 2 / \mathrm{AS}$ at both the transcriptional and the translational level. In SGC7901/AS, only ABCB1 appeared to have significant expression at both the transcriptional and the translational level. Although there was no significant inhibition of growth in two arsenic-resistant cell lines with $20 \mu \mathrm{M}$ verapamil, a standard ABCB1 inhibitor (26), two resistant cell lines partially restored the sensitivity of $\mathrm{As}_{2} \mathrm{O}_{3}$ under $50 \mu \mathrm{M}$ verapamil. The survival in the resistant group was still 10 to $20 \%$ higher than that in wild-type group. As verapamil has been considered a chemosensitizer and drug accumulator in multidrug-resistant cells expressing MRPs, arsenic compounds might be the substrates of ABC transporters and were effectively transported outside the membrane by $\mathrm{ABCB} 1, \mathrm{ABCC} 1$, and $\mathrm{ABCC} 2$, at least in HepG2/As and SGC7901/AS. 5-FU has been reportedly transported by ABCC5 and ABCC 11 only in transfection studies $(27,28)$. Although four cell lines were inhibited by 5 -FU at a concentration of $100 \mu \mathrm{g} / \mathrm{ml}$, HepG2/AS and SGC7901/AS appeared more resistant to 5-FU. This suggests that there probably are other mechanisms of arsenic resistance in arsenic-resistant cells.

Apoptosis induced by arsenic trioxide is associated with the induction of reactive oxygen species (ROS) and DNA damage (29). Then p53 and checkpoint kinases Chk1 and Chk2 are activated, thereby amplifying the DNA damage signal to execute cell cycle checkpoint regulation (30). It has been reported that apoptosis induced by arsenic trioxide is required for p53 $(14,15)$. In our study, p53 levels were increased in two arsenic-resistant cell lines which could be the result of $2 \mu \mathrm{M} \mathrm{As}_{2} \mathrm{O}_{3}$ medium, but the biofunction of $\mathrm{p} 53$ would be inhibited by some modulators. Previously, a novel oncoprotein, gankyrin, has been purified and characterized as a component of $19 \mathrm{~S}$ regulatory subunit of the $26 \mathrm{~S}$ proteasome (31), and can bind to MDM2 and facilitates the binding of MDM2 to p53, resulting in ubiquitylation and degradation of p53 (32,33). Gankyrin is overexpressed in HepG2/AS at the protein and mRNA level compared with HepG2 but is decreased slightly in SGC7901/AS at the protein level in spite of increasing at the mRNA level. The expression of MDM2 also increased in two arsenic-resistant cell lines. These findings suggest that in HepG2/AS, overexpression of gankyrin and MDM2 contribute to the inhibition of apoptosis induced by p53. In SGC7901/AS, however, gankyrin appears to have a minor part in the suppression of p53. This may be because gankyrin overexpression has been reported mostly in HCCs as playing an oncogenic role of human hepatocarcinogenesis, but no studies have shown an increase of gankyrin in gastric 
cancer cell lines or pathologic tissues. The blocking of p53dependent apoptosis may due to the overexpression of MDM2 in SGC7901/AS.

Another tumor suppressor interacting with gankyrin and MDM2 is Rb. Gankyrin competes with $\mathrm{p} 16^{\mathrm{INK} 4 \mathrm{~A}}$, an inhibitor of cyclin kinases, for binding to cyclin D-dependent kinase 4 (CDK4) (34). Subsequently, gankyrin conjugates with CDK4 and $\mathrm{Rb}$ and makes the phosphorylation of $\mathrm{Rb}$ at Ser795. Additionally, MDM2 binds selectively to hypophosphorylated $\mathrm{Rb}$, resulting in $\mathrm{Rb}$ degradation via 20S proteasome (35). In our study, there was no difference in the expression of $\mathrm{Rb}$ between two resistant cell lines and relative wild-types, whereas the phosphorylation of $\mathrm{Rb}$ at Ser795 increased in two resistant cell lines. It is known that hypophosphorylated $\mathrm{Rb}$ represses the transcription of genes controlling the cell cycle through direct protein-protein interactions. Whereas CDK4mediated phosphorylation of $\mathrm{Rb}$ at Ser795 converts $\mathrm{Rb}$ to an inactive, phosphorylated state, resulting in the release of E2F transcription factors, activation of DNA synthesis genes and cell cycle progression (36). Therefore, the arsenic resistance in solid tumor cells may partially be due to the promotion of the cell cycle by the phosphorylated Rb at Ser795, which is induced by the overexpression of gankyrin in HepG2/AS and an unknown pathway in SGC7901/AS.

From our results, we conclude that after diffusion of $\mathrm{As}_{2} \mathrm{O}_{3}$ into cytoplasm, it is actively transported outside cellular membrane by $\mathrm{ABCB} 1, \mathrm{ABCC} 1$, or $\mathrm{ABCC} 2$ in arsenic-resistant cell lines (Fig. 5). Although the amount of $\mathrm{As}_{2} \mathrm{O}_{3}$ in treated cells is decreased, the retained drugs will induce p53 in nucleus. However, the increased gankyrin and MDM2 in arsenic-resistant cells facilitate the ubiquitination and degradation of p53, thereby abrogating p53-dependent apoptosis. Meanwhile, gankyrin facilitate the phosphorylation of $\mathrm{Rb}$ at Ser795 resulting in the releasing of E2F transcription factors and cell cycle progression.

In summary, our findings suggest that chronic use of $\mathrm{As}_{2} \mathrm{O}_{3}$ may induce the expression of $\mathrm{ABCB} 1, \mathrm{ABCC} 1$, or $\mathrm{ABCC} 2$ in liver and gastric cancer cells, at least in HepG2 and SGC7901. The function of p53 in two arsenic-resistant cell lines incubated with $2 \mu \mathrm{m} \mathrm{As} \mathrm{O}_{3}$ was inhibited by the overexpression of gankyrin and MDM2 in HepG2/AS and by MDM2 in SGC7901/AS. The phosphorylation of Rb at Ser795 was increased in arsenic-resistant cells, resulting in cell cycle progression, which could be the reason of arsenic resistance. Unfortunately, although four generations of inhibitors toward $\mathrm{ABC}$ transporters have been developed, no significant effect has been reported even if the combined therapy is utilized. Reactivation of p53 is another new attractive pharmacological approach for cancer therapy $(37,38)$. The combination of $\mathrm{As}_{2} \mathrm{O}_{3}$ and small molecule inhibiting MDM2, e.g. Nutlin-3 or MI-219, may have effective anti-tumor activity in resistant and nonresistant liver and gastric cancer cells, which need to be further explored.

\section{Acknowledgements}

We greatly appreciate Mr. Pan Shang Ha, the director of central laboratory, for his support in cytobiological research and Mrs. Tao Wei Yang for her selfless assistance in molecular biological examination.

\section{References}

1. Shen $\mathrm{ZX}$, Chen GQ, Ni JH, et al: Use of arsenic trioxide $\left(\mathrm{As}_{2} \mathrm{O}_{3}\right)$ in the treatment of acute promyelocytic leukemia (APL): II. Clinical efficacy and pharmacokinetics in relapsed patients. Blood 89: 3354-3360, 1997

2. Marasca R, Zucchini P, Galimberti S, et al: Missense mutations in the PML/RARalpha ligand binding domain in ATRA-resistant $\mathrm{As}(2) \mathrm{O}(3)$ sensitive relapsed acute promyelocytic leukemia. Haematologica 84: 963-968, 1999.

3. Zhang T, Wang SS, Hong L, Wang XL and Qi QH: Arsenic trioxide induces apoptosis of rat hepatocellular carcinoma cells in vivo. J Exp Clin Cancer Res 22: 61-68, 2003.

4. Chan JY, Siu KP and Fung KP: Effect of arsenic trioxide on multidrug resistant hepatocellular carcinoma cells. Cancer Lett 236: 250-258, 2006.

5. Lin CC, Hsu C, Hsu CH, Hsu WL, Cheng AL and Yang CH: Arsenic trioxide in patients with hepatocellular carcinoma: a phase II trial. Invest New Drugs 25: 77-84, 2007.

6. Ejendal KF and Hrycyna CA: Multidrug resistance and cancer: the role of the human ABC transporter ABCG2. Curr Protein Pept Sci 3: 503-511, 2002.

7. Deeley RG, Westlake C and Cole SP: Transmembrane transport of endo- and xenobiotics by mammalian ATP-binding cassette multidrug resistance proteins. Physiol Rev 86: 849-899, 2006.

8. Keppler D, Leier I, Jedlitschky G and König J: ATP-dependent transport of glutathione S-conjugates by the multidrug resistance protein MRP1 and its apical isoform MRP2. Chem Biol Interact 111-112: 153-161, 1998.

9. Schläwicke Engström K, Broberg K, Concha G, Nermell B, Warholm $\mathrm{M}$ and Vahter M: Genetic polymorphisms influencing arsenic metabolism: evidence from Argentina. Environ Health Perspect 115: 599-605, 2007.

10. Kala SV, Neely MW, Kala G, et al: The MRP2/cMOAT transporter and arsenic-glutathione complex formation are required for biliary excretion of arsenic. J Biol Chem 275: 33404-33408, 2000.

11. Seo T, Urasaki Y and Ueda T: Establishment of an arsenic trioxide-resistant human leukemia cell line that shows multidrug resistance. Int J Hematol 85: 26-31, 2007.

12. Ovelgönne HH, Wiegant FA, Souren JE, Van Rijn H and Van Wijk R: Enhancement of the stress response by low concentrations of arsenite in arsenite-pretreated Reuber H35 hepatoma cells. Toxicol Appl Pharmacol 132: 146-155, 1995.

13. Kojima C, Qu W, Waalkes MP, Himeno S and Sakurai T: Chronic exposure to methylated arsenicals stimulates arsenic excretion pathways and induces arsenic tolerance in rat liver cells. Toxicol Sci 91: 70-81, 2006.

14. Filippova $M$ and Duerksen-Hughes PJ: Inorganic and dimethylated arsenic species induce cellular p53. Chem Res Toxicol 16: 423-431, 2003.

15. Jiang XH, Wong BC, Yuen ST, et al: Arsenic trioxide induces apoptosis in human gastric cancer cells through up-regulation of p53 and activation of caspase-3. Int J Cancer 91: 173-179, 2001. Erratum in: Int J Cancer 93: 916, 2001.

16. Yang Y, Li CC and Weissman AM: Regulating the p53 system through ubiquitination. Oncogene 23: 2096-2106, 2004.

17. Higashitsuji $\mathrm{H}$, Higashitsuji $\mathrm{H}$, Itoh $\mathrm{K}$, et al: The oncoprotein gankyrin binds to MDM2/HDM2, enhancing ubiquitylation and degradation of $\mathrm{p} 53$. Cancer Cell 8: 75-87, 2005.

18. Shao QS, Ye ZY, Ling ZQ and Ke JJ: Cell cycle arrest and apoptotic cell death in cultured human gastric carcinoma cells mediated by arsenic trioxide. World J Gastroenterol 11: 3451-3456, 2005.

19. Subbarayan PR, Lima M and Ardalan B: Arsenic trioxide/ ascorbic acid therapy in patients with refractory metastatic colorectal carcinoma: a clinical experience. Acta Oncol 46: 557-561, 2007.

20. Wu XX, Ogawa O and Kakehi Y: Enhancement of arsenic trioxide-induced apoptosis in renal cell carcinoma cells by Lbuthionine sulfoximine. Int J Oncol 24: 1489-1497, 2004.

21. Liu J, Chen H, Miller DS, et al: Overexpression of glutathione S-transferase II and multidrug resistance transport proteins is associated with acquired tolerance to inorganic arsenic. Mol Pharmacol 60: 302-309, 2001

22. Sheehan D, Meade G, Foley VM and Dowd CA: Structure, function and evolution of glutathione transferases: implications for classification of non-mammalian members of an ancient enzyme superfamily. Biochem J 360: 1-16, 2001. 
23. Wang HF and Lee TC: Glutathione S-transferase pi facilitates the excretion of arsenic from arsenic-resistant Chinese hamster ovary cells. Biochem Biophys Res Commun 192: 1093-1099, 1993.

24. Sakurai T, Ochiai M, Kojima C, et al: Role of glutathione in dimethylarsinic acid-induced apoptosis. Toxicol Appl Pharmacol 198: 354-365, 2004.

25. Leslie EM, Haimeur A and Waalkes MP: Arsenic transport by the human multidrug resistance protein 1 (MRP1/ABCC1) Evidence that a tri-glutathione conjugate is required. J Biol Chem 279: 32700-32708, 2004.

26. De Rosa MF, Ackerley C, Wang B, Ito S, Clarke DM and Lingwood C: Inhibition of multidrug resistance by adamantylgb3, a globotriaosylceramide analog. J Biol Chem 283: 4501-4511, 2008.

27. Pratt S, Shepard RL, Kandasamy RA, Johnston PA, Perry W III and Dantzig AH: The multidrug resistance protein 5 (ABCC5) confers resistance to 5-fluorouracil and transports its monophosphorylated metabolites. Mol Cancer Ther 4: 855-863, 2005.

28. Oguri T, Bessho Y, Achiwa H, et al: MRP8/ABCC11 directly confers resistance to 5-fluorouracil. Mol Cancer Ther 6: 122-127, 2007.

29. Miller WH Jr: Molecular targets of arsenic trioxide in malignant cells. Oncologist 7 (Suppl 1): 14-19, 2002.

30. Luo Y and Leverson JD: New opportunities in chemosensitization and radiosensitization: modulating the DNA-damage response. Oncologist 7 (Suppl 1): 14-19, 2002.
31. Krzywda S, Brzozowski AM, Al-Safty R, et al: Crystallization of gankyrin, an oncoprotein that interacts with CDK4 and the S6b (rpt3) ATPase of the 19S regulator of the 26S proteasome. Oncologist 7 (Suppl 1): 14-19, 2002.

32. Lozano G and Zambetti GP: Gankyrin: an intriguing name for a novel regulator of p53 and RB. Cancer Cell 8: 3-4, 2005.

33. Dawson S, Higashitsuji H, Wilkinson AJ, Fujita J and Mayer RJ: Gankyrin: a new oncoprotein and regulator of $\mathrm{pRb}$ and $\mathrm{p} 53$. Cancer Cell 8: 3-4, 2005.

34. Mahajan A, Guo Y, Yuan C, Weghorst CM, Tsai MD and Li J: Dissection of protein-protein interaction and CDK4 inhibition in the oncogenic versus tumor suppressing functions of gankyrin and P16. J Mol Biol 373: 990-1005, 2007.

35. Sdek P, Ying H, Chang DL, et al: MDM2 promotes proteasomedependent ubiquitin-independent degradation of retinoblastoma protein. Mol Cell 20: 699-708, 2005.

36. Sherr CJ: Principles of tumor suppression. Cell 116: 235-246, 2004.

37. Shangary S and Wang S: Small-molecule inhibitors of the MDM2-p53 protein-protein interaction to reactivate p53 function: a novel approach for cancer therapy. Annu Rev Pharmacol Toxicol 49: 223-241, 2009.

38. Shangary S, Qin D, McEachern D, et al: Temporal activation of p53 by a specific MDM2 inhibitor is selectively toxic to tumors and leads to complete tumor growth inhibition. Proc Natl Acad Sci USA 105: 3933-3938, 2008. 